\title{
A Shift of Ideology in the Translation of Karl May's Work Und Friede auf Erden! into Indonesian Language
}

\author{
Prasuri Kuswarini \\ Faculty of Letters, Hasanuddin University \\ Makassar, South-Sulawesi, Indonesia
}

Received: 18-04-2014

doi:10.7575/aiac.ijclts.v.2n.3p.42
Accepted: 27-05- 2014

Published: 01-07- 2014

\begin{abstract}
This paper discusses a shift of ideology occurred in the translation of the work of the German Author Karl May Und Friede auf Erden! into Indonesian Language under the title Dan Damai di Bumi! (And Peace on Earth!). The method of the discourse analysis called " topique " developed by Boltanski and Thevenot was used to find the ideology of the source text (ST). The shift of the ideology was analyzed by comparing the ST with the target text (TT) using a structural approach (syntactic and semantic) and by considering the role of the translators, Agus Setiadi and Hendarto Setiadi. According to the result of the analysis, the shift of ideology in the translation of Und Friede auf Erden! into Indonesian, caused by eliminations of parts or whole sentence and replacement of adjectives and other kinds of attributes due to Islam and particular ethnics of the Middle East countries.
\end{abstract}

Keywords: Translation, Shift, Ideology, Elimination, Replacement, Ethnics, Islam

\section{Introduction}

In the era of globalization, when geographical boundaries as well as cultural and political are becoming more liquid, the spirit to know and learn other nations, cultures and other languages increases. This condition leads to the importance of intercultural communication. The role of translation becomes central, namely as an intermediary for communications within the framework of the transfer of technology, diplomacy, politics, economics and even literature. Literary translation can also be seen as an attempt to bridge the communication between languages and cultures.

As mediator in the communication between languages and cultures, translation has the main aim of transferring the message contained in the ST into the target language (TL) as equivalent as possible. Equivalence means: the elements of the TL contain the same message with the elements of the SL. Nida classified equivalence into two types, namely formal and dynamical equivalence. Formal equivalence displays the form and content as close as possible to the original text, and dynamical equivalence take the effect on the recipient or the recipient's response as the first priority (Nida, 1964: 165-167).

In the practice of translation, particularly in translation of literary works, there is a shift in viewing translation along with the changing nature of human relationships in today's global era. Translation is no longer required to reproduce equivalence as the main purpose, but instead pursues negotiations and transactions between languages and between cultures through the mediation of a translator (Bassnett, 2002: 6). As a consequence, there will be a reduction or elimination, even betrayal. Such a phenomenon stated Bassnett, can be found in many literary translations.

A representational example is the translation made by Antonio Gramsci, Italian Communist leader (1891-1937), who translated the tales collected by the Grimm Brothers from German into Italian. Gramsci secularized all sentences containing religious meaning in the ST, by replacing them with sentences containing rational senses in TT (Lucia Borghese, in Ives and Lacorte, 2010:150-155).

As a form of cultural activities, literature reflects human life in terms of relationships with others (social) and the environment. Eagleton considered literature as the way that someone uses to connect him/ herself to writing. The structure of a society, which values internalized in an author will be manifested as mindset and worldview that motivates the statements in his/ her works. Eagleton considered this structure of value as a part of what is called ideology. Ideology is the way how we say about and believe in something (often unconsciously) based on our connectedness with the structure of power and power relations in the community where we live (Eagleton,1996: 17-20).

Ideology in translation is an interesting subject because it raises the issue of values and beliefs. Research on ideology in translation can give a picture of a collective as well as an individual values of a society depicted in ST on one hand, and the response to those of the ST given by the translator as a representative reader of the TL community. This paper is based on a research on the translation of Karl May's work Und Friede auf Erden! (UFaE!) into Indonesian under the title Dan Damai di Bumi! (DDdB!/ "And Peace on Earth!"). The research has the main aim to see the progress of translation, especially translation of literary texts in Indonesia associated with the readiness of the Indonesian of facing the globalization 
The works of Karl May have been recognized by the Indonesian since the Dutch colonial era. His works are claimed to contain messages of friendship and tolerance between nations, ethnics, and religions. However, many European researchers of May's works found that behind the idealism of the main characters in his novels, the nuance of racism and ethnocentrism remain clear. May always highlighted the superior and good German (Crancroft [1967] in Ferens, 2008: 98).

$U F a E$ ! is a collection of the journals of Karl May's journey to the Orient countries in the year 1898-1900. It also carries the idea of pluralism confronted with fanaticism, but the feel of racism and ethnocentrism is still clearly visible. The novel was first published in 1901 under the title Et in terra pax, and translated into Indonesian in 2002 by Agus Setiadi and Hendarto Setiadi with the title "Dan Damai di Bumi!" (And Peace on Earth!). The result of the analysis of the translation UFaE! into Indonesian showed the shift of ideology carried by the main character "Ich" (I), who also serves himself as the narrator. The novel is divided into several themes, each theme is about an event. Each event can be seen as a complete story. This paper is a part of a dissertation which discusses the ideological shift in translation of literary texts. The study used only the first theme, namely Am Tor des Osten (The Gate of the East), which is limited to the events in Cairo.

\section{Theories of Translation}

Translation is an activity of reproducing equivalent signs in terms of language, culture, and messages. Nida, in Toward a Science of Translating (1964) stated that translation is an attempt to reproduce equivalence. He classified equivalence into two types, namely: formal equivalence, which is oriented towards the form and content of the source language, and a dynamical equivalence, which prefers the equivalence effect on the recipient or the recipient's response. In line with Nida, Schneider (2007) also held that translation (Übersetzung): "wird als ein Vorgang dargestellt, durch den Äquivalenzen zwischen zwei Sprachen hergestellt wird und wird als ein Verkehr zwischen zwei Kulturen angesehen" (Schneider, 2007: 15-16). (should be seen as a process of reproducing equivalence between two languages, as well as a communication exchange between two cultures). The similar statement came from Larson (1984) in her book Meaning-Based Translation: A Guide to Cross-Language Equivalence. She suggested a reach of equivalence, which is moved from the form to the semantic structure. According to the principle, she stated that meaning is to be transferred, and maintained to remain constant, considering the equivalence between the ST and the TT on lexical, grammatical, and phonological aspects.

However, there is different thinking about translation, which holds that translation is no longer required to reproduce equivalence as the main aim, instead, as an attempt of acculturation (see Bassnett, 2002, and Venuti, 1992). Bassnett said that: "translation is not just the transfer of texts from one language into another, it is now rightly seen as a process of negotiation between texts and between cultures, a process during which all kinds of transactions take place mediated by the figure of the translator" ( Bassnett, 2002: 6). Since translation has been seen as a process of negotiation and transactions, there are consequences to be faced, namely: disappearance or eliminations and betrayal (Bassnett, 2002:8), because there are shifts of views from those of the ST to those of the TT.

Likewise, Venuti realized the phenomena, and suggested the use of translation strategies, which can display the result of acculturation in class, gender, sexual orientation, race, ethnicity, politics, etc. For it must be anticipated that some effects such as elimination or addition, may arise. In Rethinking Translation, he said that contemporary translation aims: "to provoke a rethinking of translation that is philosophical, but also political, engaged in questions of language, discourse, and subjectivity, while articulating their relations to cultural difference, ideological contradiction, and social conflict" (Venuti,1992: 6).

\section{Ideology}

The term „ideology“ was first introduced by Destutt de Tracy (1754 - 1836), an 18th century French thinker, who said that: there were no innate ideas, all thought being derived from sensation (Hawkes, 1996: 55; Thompson, 1990: 30) .

The concept of ideology of capitalism of Karl Marx (1818 - 1883), a 19th century German political philosopher, was based on the phenomenon occurred in the era of modernism (late 19th, early 20eth century). According to Marx we fetishize the works of men's hands and transform the subject into an object. Marx talked about the exchange value that could be interpreted as an explanation for our inability to realize the nature of things. It leads to commodity fetishism, which means: we eventually no longer see the real value of something, but only the appearance (Hawkes, 1996: 96-98). It underlies the formation of ideology as false consciousness, which is resulted from the connection between ideas and material, that is mediated by representation.

Georg Lukacs (1885 - 1971), hungarian philosopher and marxist literary critic, borrowed the concept of Aristotle (384$322 \mathrm{BC}$ ), namely the second nature. Lukacs stated: „Men erect around themselves in the reality they have created and "made", a kind of second nature which evolves with exactly the same inexorable necessity as was the case earlier on with irrational forces of nature“. (Hawkes, 1996: 112).The term was meant as human creation, which is held as sacred, functioning as a medium of worshipping God or another supernatural.

False consciousness is also part of the game by using language as ingredients. Jürgen Habermas (1929 -), a member of the second generation of the Frankfurt School described false consciousness as systematic deviations of communication, therefore, the public should be made aware and be freed from the shackles of ideology, and that is the task of ideological criticism (Eagleton, 1991: 14; Hardiman, 2009: 210). 
However, Antonio Gramsci (1891 -1937), leader of the Italian Communist Party and Marxist thinker, didn’t agree with the concept of false consciousness. He also departed from the false consciousness of Marx's thesis, but saw ideology as something consciously constructed. It is a practical form of power. According to Gramsci, ideology is willed and constructed by the existence of class conflict that led to the concept of hegemony (Hawkes, 1996: 117).

In line with Gramsci, Louis Althusser (1918 - 1990) argued that ideology is material, not ideal. He pointed to the indirect relationships that are affective and done unconsciously by the world around us and the ways we involve in social reality. Althusser's concept of ideology is more subjective, focused on subject. Ideology is something that makes us unique, one is different from another. Ideology forms essentially our identity. According to Althusser, ideology is a certain way how we interpret everything that makes us (human), act as a social subject, and build relations, in which we as subjects, are connected with the dominant relations of production in society (Eagleton: 1991: 18-19; Hawkes :123-126; Weedon, 2004: 5-12). Althusser's definition of ideology is used as the basis for the analysis of ideology in this paper. His concept of ideology is broken down into a form of analytical method by Boltanski and Thevenot, which then modified by Jean Pierre Malrieu. The method is applicable especially for analysing literary texts.

\section{Ideology as Structure}

Jean Pierre Malrieu, a french linguist, asserted that modern ideologies little to do with doctrine and principles. They highlight patterns or relations of a system, and utilizes the language system. Therefore, ideology, he argued, is a matter of structure. Malrieu modified the method called ,topique', which was developed by Boltanski and Thevenot, French linguists. Both of these experts have examined various types of discourse, who then got a set of expressions that are typical. The result of their study tapered into six patterns of grammatical categories, which are applicable to any kind of discourse. These categories relate to: (a). World of inspiration, (b). The domestic world,(c). The world of opinion, (d). The civic world, (e). The mercantile world, (f). The industrial world. The six categories are called grammatical categories of the discourses of justification. Each category can be explored through identification and analysis of lexical units and grammatical semantics associated with the categories. Malrieu broke down the six categories into 14 elements of ideology as follows: (a). Common superior principle [beings are compared and evaluated with respect to their capacity to conform or to behave according to this principle]; (b). State of grandeur [ideal state of superiority which determines the various, ranked states of grandeur]; (c). State of smallness [state of inferiority]; (d). Dignity [the feature of human nature which allows subjects to participate in the economy of grandeur]; (e). Grand subjects [grand beings]; (f). Small subjects [the inferiors]; (g). Objects [status symbols and environments in which grandeur is made objective]; (h). Investment [sacrifice by which subjects acquire grandeur]; ( i). Relations of grandeur [the way in which grand beings comprehend, express, realize small beings the way in which small beings participate in this relationship]; (j). Relations [natural relations between subjects and objects, subjects and subjects, objects and objects, which are regulated by their respective grandeur]; (k). Figures [context which are likely to produce optimal distributions of the states of grandeur]; (1). Test [passing test gives access to grandeur]; (m). Judgment [expression of the outcome of the test]; (n). Evidence [type of evidence supporting judgement] (Malrieu, 1999: 41-49).

5. A Shift of Ideology in Translation of Und Friede auf Erden! into Dan Damai di Bumi! [And Peace on Earth!] The episode „Cairo“ opens the novel UFaE!. The narrator in this story is "Ich" (,Saya“/"I" in TT) who appears himself as the author of the story. "Ich" accompanied by Sejjid Omar, his loyal servant who came from the Arab tribes. Omar, thanks to the strategy pursued by "Ich", was willing to rescue Waller, an American missionary, who was nearly killed by a group of Bedouin men, because he has insulted Islam. Omar, the servant, was initially arrogant to be a Muslim, but then turned to be tolerant.

Waller was the center of attention in this episode, who represented the dominance of the american super power. He tried to apply the dominance on a mission of converting as many as possible people to Christianity, by force and verbal abuse.

Waller had a daughter named Mary. Unlike Waller, Mary was a duplicate of her mother, a german woman, who was gentle and kind hearted. Waller intended to convince two Chinese, Fu and Tsi, that Christianity was the best way of life, but he failed. The characters in this episode are: (1) "Ich", who also acts as narrator, (2) Omar, a donkey shepherd, (3) Waller, an american missionary, who stopped a while in Cairo on his way to China , (4) Mary, the daughter of Waller, (5) $\mathrm{Fu}$, chinese diplomat who was on his way from Paris to China, and (6) Tsi, his son.

In addition there are other figures, namely Levantiner and Bedouin pilgrims, whose presence complemented the picture of the character "Ich". The selected episode is about people of different nationalities and religions. Conflict between the characters with different backgrounds was inevitable, but it could be resolved.

The analysis of ideology of the ST using the method topique came to the result that pluralism is the idea promoted in this novel, opposed to fanaticism. But the idea was grounded on the 19th-century Orientalism which was overshadowed by ethnocentrism and racism. The following discussion shows the shift of pluralism in ST to pluralism with different shades in TT. The characters that carried the idea of pluralism were "Ich", Mary, Fu and Tsi while fanaticism is represented by the figures Waller and the Bedouin pilgrims.

\subsection{A Shift of Orientalism}

Edward Said defined Orientalism as follows: (a) „Anyone who teaches, writes about, or researches the Orient - and this applies whether the person is an anthropologist, sociologist, historian, or philologist - either in its specific or its general aspects, is an Orientalist, and what he or she does is Orientalism“. (b) „Orientalism is a style of thought based upon an ontological and epistemological distinction made between „The Orient“" and (most of the time) ,the Occident' ““ (c) „Orientalism can be discussed and analyzed as the corporate institution for dealing with the Orient - dealing with it by 
making statements about it, authorizing views of it, describing it, by teaching it, settling it, ruling over it: in short, Orientalism as a Western style for dominating, restructuring, and having authority over the Orient". (Said, 2003:2-3).

Said asserted the statement that Orientalism is a form of authority that created by the West (Occident) to everything related to the East (Orient). The following description shows the attempts of blurring the traces of Orientalism in $U F a E$ ! through translation.

The character "Ich", who acted also as the narrator in the novel, had in life the main principle: calculations, selfconfidence, and spirituality. Calculation is: ,the process of using your judgement to decide what the results would be of doing something“ (Hornby,2005: 210). "Ich" always take into account every step he took, one of which was when he took a detour to get back to his hotel in order to avoid the convoy of Bedouin pilgrims who were returning from Mecca. Here is a reason for the action taken by "Ich", which is not translated:

[1] Sie haben sich eine fanatische Erregung hineingearbeitet, durch die sie für Andersgläubige gefährlich werden können. Ich hütete mich also, mich quer durch diesen Zug zu drängen, und wartete lieber, bis er vorüber war. Später am Abend war zu hören, dass am Meidan Abdin einige nicht so vorsichtige Europäer von diesen Leuten halb totgeschlagen worden waren. (UFaE!: 27) [They have absorbed a vibration of fanaticism into their souls, that can harm the followers of other faiths. I resisted the temptation to sneak into the procession, and better to wait until they pass. It was then heard in the evening, that in Meidan Abdin some not too careful European were beaten almost to death by the group.]

The quoted statement of „Ich“ above illustrates the incident when the group of Bedouin pilgrims was returning from the holy land, Mecca, and moving into the city of Cairo in a provocative way by brutalizing the people who presumed of having different faith. The use of the adverb: (wartetel waited) lieber (better to wait) on the data above shows the calculative action of "Ich", which is done based on the subjective judgment, even prejudice, and bigotry that the symptoms have mastered the hearts of every congregation in a statement: Sie haben sich eine fanatische Erregung hineingearbeitet,... (They have absorbed the vibrations of fanaticism into their soul, ...). Furthermore, based on prejudice "Ich" predicted the actions that can or will be done brutaly by the group of pilgrims, which is expressed by the phrase: ....., durch die sie für Andersgläubige gefährlich werden können (..., which may endanger others of another beliefs.). The use of the modal verb können is often based on an experience of the subject that a particular action in a particular environmental conditions are often confronted with obstacles or problems (Weinrich, 1993: 297). "Ich" has predicted these obstacles, so he then decided to wait until the procession had passed. Justification for the action taken is shown by the last sentence in the data, which mentions, that ,in the evening the news spread..." (Später am Abend war $z u$ hören), that in Meidan Abdin (dass am Meidan Abdin) some not too careful Europeans were almost died from being beaten (einige nicht so vorsichtige Europäer von diesen Leuten halb totgeschlagen worden waren). However, the statement regarding the event of the beating that ends in the death is not translated into the TT, because it gives publicly a very negative picture of the Muslim, who just returned from Mecca. Therefore, the translators and publishers made a careful decision of not reproducing such a sensitive matter.

The elimination of the sentence in the data [1], which showes one of the calculative actions of „Ich“, caused the loss of his negative opinion on the Bedouin pilgrims. As the consequence, the character Saya (,I“) in the TT as the equivalent figure to "Ich", became more neutral.

Another principle of life of "Ich" is „self-confidence“, as showed on the sequences when he saved Waller and his daughter, Mary, and the two chinese men, $\mathrm{Fu}$, and his son Tsi, from a desert trial conducted by a group of Bedouins. The trial was a response to a big mistake made by Waller, who was accused of insulting Islam. But the heroic action of "Ich", still shows its negative view on the Bedouins, and indirectly about Islam, for bringing the name of the Prophet Mohammed in his statement. However, the contradictory attitudes do not appear in the TT, as can be seen from the following data:

[2] „,Es ist eine Beledigung geschehen, die nur mit Blut gesühnt werden kann. Ich will es dir erzählen.....Er berichtete mir, natürlich in seiner muhammedanisch gefärbten Weise, was geschehen war. (UFaE!: 75) [Here happened an insult, which has to be atoned by blood. Let me tell you the story..... He (the Bedouin) reported the event of course in his mohammedan way]. The translated version in the TT is:

"Di sini terjadi penghinaan yang harus dibayar dengan darah. Ijinkan saya menceritakannya. Ia melaporkan kejadian yang dialaminya, tentu saja dari sudut pandangnya sendiri, dan .. “(DDdB!: 69) [Here happened an insult, which has to be atoned by blood. Let me tell you the story.... He (the Bedouin) reported the event of course from his own point of view.]

In addition to the statement of the Bedouin representative quoted above, tucked the response of "Ich" against the report, that is: ....in seiner muhammedanisch gefärbten Weise, ... The phrase is built of a predikative-adjective: gefärbt (participle form of the verb Färben: Coloring), and classifying adjective: muhammedanisch, which gives emphasis to the classificative noun Weise (way), so that the meaning of the utterance is:" ... in a way that is colored by mohammedan style“. This statement implies a certain perception of "Ich" about the Prophet Muhammad. In the TT the statement has been changed into: "... of course from its own point of view". The change shows us that there is a shift of point of view, which generalizes (natürlich in seiner muhammedanisch gefärbten Weise/ of course in his mohammedan way) became personalizes (tentu saja dari sudut pandangnya sendiri/ of course from his own point of view). 
The term Muhammedaner and "Muhammedanism" came from the understanding of medieval Christian thinkers who applied the analogy of Jesus and Christianity, to Muhammad and Islam. Muhammad thus automatically got a predicate "cheater", because he assumed to imitate Jesus (Said, 2003: 61). Compare this analogy with the statement of the antagonist in UFaE!, Waller, the missionary, as seen from the following quotation, which is not translated in the TT:

[3] Schau dir da den Eselsjungen an! Sein Allah ist ein falscher Gott und sein Muhammed ein Lügner. So viele Türme da unten ragen, in so viele Moscheen möchte ich treten, um laut auszurufen, dass es kein anderes Heil als das unsere gibt. (UFaE!: 19) [See the donkey shepherd there! His God is a false God and his Muhammad is a liar. So much towering minarets down there, I will enter for calling loudly, that there is no salvation apart from that we offer.] On the surface, the principles of „calculation“ and „strategy“ have not changed in the TT, although in the ST they stand on religious prejudice against Muslims.Other element of ideology is „state of grandeur“. The result of the analysis shows that the element of ideology contains: knowledge, ethics, and reputation. However, the translation caused a shift in the aspect of "knowledge". "Ich" is described as a figure who is knowledgeable, especially about the Orient and the Islamic world, as shown in the following data:

[4] Von der Alabastermoschee bis nach Kasr el Ain hinüber und von der ahnenhaften Amr Ibn el Adi bis zur früheren Ez Zahir hinunterklangen die in Stein gedichteten tausend Strophen der Minarehs zu Allahs Thron empor. (UFaE!: 11) [From the Alabastermosque up to Kasr el Ain, and from the ancestor Amr Ibn el Adi to Ez Zahir, echoed the verses carved on the stones of the minarets to Allah's throne].

The translated version in the TT is:

Dari Mesjid Pualam sampai Kasr el Ain dan dari Amr Ibn el As sampai Ez Zahir, ribuan muazin mengumandangkan asma Allah dari puncak menara mesjid (DDdB!: 7) [From the Marblemosque to Kasr el Ain, and from Amr Ibn el to Ez Zahir, thousands of muezzin echoed the holy names of Allah

from the top of the minarets.]

The sentence in the ST constructed as an intransitive sentence:

Von der Alabastermosche/ From the Alabastermosque (adverb, local); hinunterklangen / echoed (predicate); die, in Stein gedichteten Strophen der Tausend Minarehs / the verses carved on the stones of the thousands of minarets (subject); zu Allahs Thron empor / to the throne of God above (adverb, local), while the version in the TT is in a transitive form:

Dari Mesjid Pualam/ from the Marblemosque (adverb, local); ribuan muazin/ thousands of muezzin (subject); mengumandangkan/ echoed (predicate); Asma Allah/ the holy names of Allah (objects); dari puncak menara mesjid/ from the top of the minarets" (adverb).

The difference in structure has an impact on the meaning of the sentence, which also changed. The sentence in the ST explaines that the sounds echoed from thousands of minaret were written on stones, while the sentence in the TT shows the role of the muezzin echoing thousand names of Allah. „Ich“ or the narrator in the ST assumed that something echoed from the minarets were verses of poetry (gedichtete Strophen). The translator made a correction by replacing the wrong statement in the ST with the correct one according to his knowledge about Islam. A similar correction can be seen in the following data:

[5] Hierauf legte er die Hände auf die Knie, neigte den Kopf, verbeugte sich dreimal und sagte: ... [he laid his hands on the knees, bowed the head, bowed himself three times and said:...] The translated version in the TT seen as follows:

Sejjid Omar meletakkan tangan di lutut, membungkuk seraya menundukkan kepala, dan berkata:... Sejjid Omar laid (his) hands on (his) knee, bowed himself while sinking his head, and said. .....).

The Data [5] shows the partial removal of the sentence, namely: .. verbeugte sich dreimal und sagte ... (... bowed himself three times, and said ...) to describe a motion of prayer called tasyahud. The explanation about the three times bowing while sitting as a part of praying ritual in the Indonesian islamic tradition is not correct. Therefore, the translator made an adjustment, which is acceptable in the islamic society. In the ST "Ich" is a European (German) who is described as having a thorough knowledge of the Islamic world and the Orient. Through this fact can be assumed that the knowledge of "Ich" was based on Orientalism of the 19th century, namely the understanding of the western society towards the Orient and the Islamic world, which is often colored with misunderstanding. Misconceptions found in some parts of the ST were corrected in the TT by replacing some of the statements and illustrations in the ST that are considered wrong, particularly with regard to Islam. Still in the context of a story about the breadth of knowledge of "Ich", the following data shows the shifts of the view of "Ich" against the indigenous population, the Bedouin:

[6] Die gestern auf dem Platze Ibrahim Pascha beobachteten fremden Pilger waren heute heraus nach den Pyramiden gezogen, um ihnen, die für den Wüstenbewohner noch größere Wunderwerke als für uns zivilisierte Menschen sind, einen Besuch abzustatten.(UFaE!: 61 )[the strange pilgrims seen yesterday on the Ibrahim Pascha square were going out today for visiting the pyramids, the wonderworks, that are held greater by the desert people as by us, civilized people]. The statement was changed in the TT as follows:

Rombongan peziarah asing yang kemarin terlihat di lapangan Ibrahim Pascha hari ini berkunjung ke kompleks piramida, yang bagi para penghuni gurun itu lebih menakjubkan lagi disbanding bagi orang barat (DDdB!: 55) [the delegation of the strange pilgrims seen on the field of Ibrahim Pascha yesterday, was visiting the pyramids today, which were more remarkable for the desert people, than for the Westerners] 
The data [6] shows an example of weakened expressions. Several statements as such seem to be cornering the Islamic groups. The ST compares a group of muslim Bedouins with Europeans. The Bedouins are implicitly considered uncivilized, seen from the form of participle adjective zivilisiert/civilized, which refers to the European. The replacementl of the participle adjective attached to the noun Menschen (human, people), which refers to the pronoun of the first person plural in accusative, uns (us, European), with "the westerners" weakened the intention of the author.

Elimination of a sentence or few sentences, and replacement of particular adjectives on the data quoted above give an effect of weakening the view or opinion of "Ich" or the narrator in this story, against the indigenous people of Egypt, particularly against Muslims. Although "Ich" is described as a wise pluralist, but traces of arrogance as European/ Westerner cannot be hidden in the ST. His arrogance shows itself in the form of negative attributes, that are attached to the people he observes.

The traces of Orientalism also found in the element of ideology ,grand objects“ ( the most valuable achievement). The grand object for "Ich" is pluralism. His views can be inferred from the chain of events when he made reflections about: (a) the history of religions in the lands of the Orient; (b) about human equality, and (c) about the intelligence and wisdom of $\mathrm{Fu}$, which indirectly indicates his approval for the views of Confucianism; etc. His reflections give an impression that he respected other beliefs and tolerance. The shift occurred in the element ,grand object" caused by significant changes in the data [7], which displays the statement of Mary, Waller's daughter, about Orient and Occident which is not translated into the TL:

[7] Er ist für mich ein schlafender Prinz im stehen gebliebenen Saale einer eingefallenen, morgenländischen Königsburg. Seine Bestimmung ist, von einer abendländischen Jungfrau aufgeweckt zu werden. Wenn dann durch beide der Osten mit dem Westen in selbstloser Liebe vereinigt ist werden alle Völker der Erde glücklich sein. "(UFaE!:.17) $[\mathrm{He} /$ the Orient is to me like a sleeping prince in the hall of a royal castle of a land of rising sun, that remains . His destiny is, that he will be awakened by a virgin of the land of sunset. If, through them, the East and the West can be united in an unselfish love, all the people in this world will be happy.].

The Data above explains that the Orient or the East countries are like a sleeping prince. As a prince he had all the image of pomp and grandeur, but his state as a sleeping prince, gives him an image of a powerless figure. The existence of the prince is determined by a girl from the Occident or the western country. The unity of both will make the world happy. Mary's statement implicitly signalizes a dream of „Ich“: to unite East and West with "guidance" from the West (Seine Bestimmung ist von einer.../ his destiny will be determined by [data 21]). That was a collective idea of Europeans in the 18th century, starting from the French invasion of Egypt in1798. Since then Orientalism introduced by western nations (Europe) in from of sciences that underly the development of various ideas, such as: Positivism, Historicism, Racism, even Imperialism. These ideas lead to a certain belief, that Europe as a representation of the West, is superior, and have the rights to "take care" of the East or the Orient, that is weak and incompetent of taking care of himself (Said, 2003: 41-49).

Mary's statement which is agreed by "Ich" is not translated because it placed the "East" (Orient) is as the weaker party, which can only rise when aided by the "West".

\subsection{A Shift of Ethnocentrism and Racism}

Ethnocentric and racial view was found in the element of ideology „,common superior principle“, namely in the principle of "self-confidence" of "Ich". The ethnocentric and racial view emerged especially in his comments about the Levantine who was in Cairo to make a living as a tour guide. However, ethnocentrism and racism also faded in the TT, as shown by the following example:

[8] Der Levantiner hätte es vielleicht, aus Rachsucht mit Hilfe des Eseltreibers mit mir anzubinden; aber es ohne diese Unterstützung zu tun, dazu war er, wie die meisten seinesgleichen, zu feig. (UFaE!:14) [Obsessed by a will to take a revenge on me, the Levantine seemed to hold me a grudge by inducing the donkey shepherd, but he had no support from the shepherd. Without the support, he, like his equals, was a coward.]

Laki-laki peranakan itu tampaknya menyimpan dendam dan berusaha menghasut si gembala keledai untuk mencari perkara dengan saya; namun karena tidak mendapat dukungan, ia pun tidak berani berbuat sesuatu. (DDdB!: 10) [the man of mixed race seemed to plan of taking a revenge on me, and tried to induce the donkey shepherd to hold me a grudge; but, because he didn't get support, he didn't dare to do anything].

The quoted parts of the ST above come from the events in the hill called Dschebel Gijushi, a place visited by many tourists in order to see Cairo and the surrounding areas. In that event "Ich" commented on the people he saw on the hill. On a man he described as a Levantine, who wanted him out of that place, he commented: Dazu war ... er, wie die meisten seinesgleichen, zu Feig. [to do such a thing, he, like his equals, was too cowardly, pen.).

The opinion about the Levantine who was too cowardly to throw him out, shows the great confidence of "Ich". He was very sure that the Levantine was no match for him. The translation of the adjective zu Feig (too cowardly) into tidak berani berbuat sesatu (dare not to do anything), shifted the character of the Levantine. Cowardice is an inherent nature of a person, while "do not dare to do anything" is temporary and contextual. Levantiner itself means: Bewohner von der Levante gemischt europ.- oriental. Herkunft / European and Oriental mixed-blood population of Levante (Wahrig, 1991: 833). But there is another meaning of the term Levantiner in German, that is: gerissener handler / cunning traders. (Brockhaus, 1984: 478). From both explanations can be concluded, that in the German word Levantiner there is negative connotation with ethnocentric and racial nuance. This view was reinforced by the use of the genitive 
predicative (Prädikats-Genitiv): seinesgleichen, which means "like his equals". Another stereotypes attached to the Levantine can be seen as follows:

[9] Als dritten Reiter bemerkte ich einen jener christlichen oder jüdischen Levantiner, die jedes von ihnen gehörte, wenn auch gänzlich unverstandene fremdsprachige Wort in dem Mehlwürmertopfe ihres Gedächtnisses sorgfältig aufbewahren, um sich dann, wenn sie mit diesen Würmern nicht mehr allein fertig werden können, für Dolmetscher auszugeben und sie gegen mögllichst hohe Vergütung an den Mann zu bringen.(UFaE!: 12) [I noticed one of those Christian or Jewish Levantines as a third rider, who owned foreign language words, even if completely misunderstood, that were carefully stored in the mealworms pot of their memory. When they were overwhelmed by the worms, they pass themselves off as Interpreters and sell their abilities with the highest reward].

The quoted sentence was translated into Indonesian as follows:

Penunggang ketiga ternyata laki-laki peranakan Eropa-Timur Tengah dari golongan Kristen atau Yahudi, yang dikenal gemar menghapalkan setiap kata asing yang pernah mereka dengar, tanpa memedulikan artinya. Ketika otak mereka akhirnya tak sanggup lagi bergulat dengan semua kata itu, mereka lalu mengaku sebagai jurubahasa dan berupaya menjual kemampuan mereka dengan imbalan yang stinggi-tingginya. (DDdB!: 9) [The third rider was a male, a mixedblood of Eurasian and Middle Eastener from Christian or Jewish groups, known likes to memorize any foreign word he has ever heard, regardless of the meaning. When their brain could finally no longer wrestle with all that said, they are then admitted as interpreter and attempt to sell their abilities with the highest reward.]

Sarcasm [Data 9] shown through the phrase: Mehlwürmertopfe ihres Gedächtnisses, which consists of compound word Mehlwürmertopfe. The word Mehlwürmertopfe is derived from the nouns das Mehl (flour); der Wurm (worm, grub, caterpillar); der Topf (pots, pan, containers ), which means "pan or pot of flour worms". The attributive genitive ihres Gedächtnisses, which comes from the possessive pronoun ihr (theirs) and the noun Gedächtnis (memory), determined the meaning of the whole nominal phrase, that is "pot of memory containing wheatworms". Compared with its equivalent in the TT which reads " gemar menghapalkan setiap kata asing..., (memorize any foreign word ...), a very lowering impression in the ST is faded in the TT. The transformation of the noun Würmern (etwas Nagendes, Bohrendes / something gnawing, perforating,) into semua kata itu/ ,all the words", weakened the expression in the ST, that showes how difficult foreign words to the uneducated Levantiner. Through the sarcastic style can be read the personal perception of the narrator that is very negative towards the Levantine.

Another example of sarcasm pointed to the Levantine is:

[10] Eine Weile ließen sie es sich gefallen, dann aber gebot die Dame dem Polyglott-schrecklichen Griechen still zusein, zog ein rotgebundenes Buch aus der Tasche und sagte zu dem Herrn, zu meiner Überraschung in deutscher Sprache:.. (UFaE!: 4) [They tried to be patient for a while, but then the lady begged the polyglot-awful Greek to be quiet, she took a book with a red cover from her bag and said to the gentleman, to my surprise, in German]

The translated version in he TT is:

Beberapa saat mereka mencoba bersabar, tetapi akhirnya perempuan muda itu mengisyaratkan agar si juru bahasa tutup mulut. Ia mengeluarkan buku bersampul mereah dari tas dan kepada pria yang menyertainya ia berujar, di luar dugaan saya dalam bahasa Jerman (DDdB!: 11) [They tried to be patient for awhile, but finally the young woman gave the interpreter a sign to shut up. She took a book with a red cover from her bag and said to the accompanying man, to my surprise in German.]

The statements of the narrator or "Ich" in the ST containing negative prejudice against the Levantine, is also implicit in the data [10]. The head of the nominal phrase in the dative case dem-schrecklichen Polyglott Griechen is the noun der Grieche (the Greek). Polyglott-schrecklich is an adjective formed by the noun (der) Polyglotte, or adjective polyglott, which means someone who can speak several foreign languages, and the adjective schrecklich (furchtbar, Entsetzlich, grauenvoll / scary, awful). Through the nominal phrase can be seen that the narrator dislikes a particular ethnic mentioned: dem Griechen (the Greek). But the translator changed the proper name referring to a particular ethnic (the Greek) with a proper name referring to a profession (interpreter), and removed all the negative attributes attached to it.

\subsection{Translator and a Shift of Ideology}

Translators are generally people who have a different background from the author. The different background will bring a lot of influence on the translation. In addition to the effect of different backgrounds, the publisher whose demands are usually oriented towards market, as well as towards social and psychological conditions in the society of the TL, also plays a role in a translation process. This condition is experienced by the team of translators and editors of the novel UFaE!, as can be read in the e-mail from Pandu Ganesha, guest editor for the translation UFaE! into DDdB! as follows:

Menurut orang Jerman masa kini, mereka mengakui bahwa salah satu kelemahan Karl May, atau tepatnya orang Eropa abad 19, bahwa dari segi keagamaan, ia menganggap Kekristenan adalah superior, konsekwensikan yang non-kristen adalah inferior. Tapi itu adalah budaya mereka, mau apa lagi.

[According to the German people of today, they acknowledge that one weakness of Karl May, or rather the Europeans of the19th century, was in terms of religion. They considered Christianity to be superior, automatically non Christian was inferior. But it was their culture, there is nothing we can do against it.] 
Karena bukunya akan dikonsumsikan kepada khalayak muslim, tentunya si penerbit harus peka dan berhati-hati. Yang saya ingat, pihak penerbit berpendapat, selama itu tidak mengubah arti, maka kalau ada yang sensitif, sebaiknya dihindari. Dari pengalaman saya di buku lain (Kara Ben Nemsi, yang menceritakan petualangan di Mekkah), saya menambahi dengan appendix, penjelasan dari intelektual muslim, jadi aman.

[Because the book will be consumed to Muslim audiences, of course, the publisher must be sensitive and careful. I remember, the publisher argued, ,as long as it does not change the meaning, then if there is something sensitive, it should be avoided“. From my experience with other books (Kara Ben Nemsi, which tells the adventures in Mecca)

The explanation of the editor quoted, refers to the consumer or reader of the TT. It means, the changes made by the team of translators and editors are a form of social responsibility towards the society of the TL.

\section{Conclusion}

The result of the analysis of the translation of UFaE! into Indonesian showed a shift of ideology. Pluralism which based on orientalism in the ST was transformed into Pluralism, that accommodated the interests of the society of the TL, especially the Muslims. The ideology pluralism that should have been highlighted in the ST overshadowed in fact by other ideologies, namely orientalism with ethnocentric and racial nuance. The side ideologies regard the Islam and a particular ethnic group in the Levante. Technically, the ideological shift occured due to: (a) removal or replacement of adjectives and various attributes that determined some nouns; (b) reduction or elimination of words, phrases, sentences, to paragraphs containing opinions or thoughts of the characters; and (c) stylistic changes. All the changes were made as a form of a responsibilty of the translator to the society of the TL.

The translation of the novel UFaE! into $D D d B$ ! has blurred the traces of Orientalism contained in the text. Furthermore, the genuine identity of the author with his perspective on the Eastern World and Islam is shifted. It is then of importance to discuss to what extent the authority of the translator could be applied in translation of literary texts. The shift of ideology shows that the Indonesian society is not yet fully ready with the disclosure of information in the global era, when criticism and dissent become part of the everyday traffic of information.

\section{References}

Bassnett, Susan. (2002). Translation Studies. London, New York: Routledge,

Brockhaus, F.A. (1984). Der Sprach Brockhaus. Wiesbaden: F.A.B

Eagleton, T. (1991). Ideology: An Introduction. New York, London: Verso,

.... (1996). Teori Sastra: Sebuah Pengantar Komprehensif. Translated by Harviah Widyawati dan Evi Setyarini. (2006). Yogyakarta: Jalasutra,

Ferens, D. (2008). “A Confidence Man in Africa: Karl May and the German Colonial Enterprise.” Special issue of Werkwinkel 3 (1). https://repozytorium.amu.edu.pl/jspui/bitstream/10593/8033/07-ferens-k.pd.

Hardiman, F. (2009). Kritik Ideologi: Menyingkap Pertautan Pengetahuan dan Kepentingan bersama Jürgen Habermas. Yogyakarta: Kanisius

Hawkes, D. (1996). Ideology. New York, London: Routledge

Hornby, A. (2005). Oxford: Advanced Learner's Dictionary. Oxford: Oxford University Press

Ives, P. \& Rocco L. (2010). Gramsci, Language, and Translation. Lonham, Boulder, New York: Lexington Books

Larson, M. (1984). Meaning Based Translation: A Guide to Cross-Language equivalence. Lanham, Maryland: University Press of America

Malrieu, J. (1999). Evaluative Semantics: Cognition, Language, and Ideology. New York, London: Routledge

May, K. (1958). Und Friede auf Erden. Radebeul, Bamberg: Karl-May-Verlag,

... (1958). Dan Damai di Bumi. Translated by Agus Setiadi dan Hendarto Setiadi. 2002. Jakarta: Kepustakaan Populer Gramedia

Nida, E. A. (1964). Toward a Science of Translating. Leiden: E.J.Brill

Said, E. (2003). Orientalism. London: Penguin Books

Schneider, H. (2007). Allgemeine Übersetzungstheori: Verstehen und Wieder-geben. Bonn: Romanistischer Verlag

Thompson, J. B. (1990). Ideology and Modern Culture. Cambridge: Polity Press,

Venuti, L. (1992). Rethinking Translation: Discourse, Subjectivity, Ideology. In Venuti, Lawrence (Ed.). Introduction (pp. 1-13). New York, London: Routledge.

Weedon, Ch.. (2004). Identity and Culture: Narratives of Difference and Belonging. Berkshire: Open University Press Weinrich, H.(1993). Text grammatik der deutschen Sprache. Zürich Mannheim, Leipzig, Wien: Dudenverlag 